\title{
ISLAMIC PRINCIPLES AND WORLD PRINCIPLES OF THE STATE
}

\author{
PhD, Doktorant Elza Shamuratova, \\ Uzbekistan, Samarkand State Institute of Foreign Languages
}

DOI: https://doi.org/10.31435/rsglobal_sr/31052019/6495

\section{ARTICLE INFO}

Received 26 March 2019

Accepted 17 May 2019

Published 31 May 2019

\section{KEYWORDS}

Family,

faith,

religious value,

education.

\begin{abstract}
In this article constituting family education based on the Islamic religion and keeping its productive perfectly, its systematic, consistency, continuity key results are main factor in Islamic rituals its consistency is the process of development of Islamic knowledge according to teaching youngsters from simplicity to complexity stages. And its systematic relation is identified with person's upbringing which is impossible with family education and it is not neglected in our country.
\end{abstract}

Citation: Elza Shamuratova. (2019) Islamic Principles and World Principles of the State. Science Review. 4(21). doi: 10.31435/rsglobal_sr/31052019/6495

Copyright: (C) 2019 Elza Shamuratova. This is an open-access article distributed under the terms of the Creative Commons Attribution License (CC BY). The use, distribution or reproduction in other forums is permitted, provided the original author(s) or licensor are credited and that the original publication in this journal is cited, in accordance with accepted academic practice. No use, distribution or reproduction is permitted which does not comply with these terms.

Introduction. The Constitution of the Republic of Uzbekistan recognizes that the right to education and upbringing has been recognized and guaranteed in the person's freedoms and social rights. Consequently, the future generations and citizens' educational needs for Islamic values and Islamic education are their rights guaranteed by our country's Constitution and that is the responsibility of the family. "Recognizing and protecting human rights and freedoms is a state duty". In addition, the National Program for Personnel Training states that through the system of continuous education, which is closely linked to the intellectual, spiritual and moral upbringing of the individual, the state is required to form a co Consequently, one of the main constitutional rights of the state is the responsibility of the state to exercise the right to education, to demonstrate creative abilities, intellectual development, to work in the profession. However, in our case and in our conviction, the institution of the family is responsible for the intellectual and spiritual and moral upbringing of the person in the formation of Islamic values. completely developed citizen and to take over the task of the state. The principle of consistency, continuity and continuity is of paramount importance in the organization and effective conduct of family educational activities and its effectiveness.

Research results. The view that the educational and educational process should be consistent and systematic was interpreted by Yan Amos Komenskiy in The Great Didactics. Consequently, it is crucial that the education and training process be consistent and systematic in the family. Its sequence is the process of forming the knowledge of Islamic values gradually, indirectly and forming in the minds of the child, from simple to complex. His systematic approach is related to the fact that the family education process is recognized as an integral part of the formation of the individual, not in our country.

It is known that gradual and systematic education is the transition from $\rightarrow$ to + unknown, easy to $\rightarrow$ dinghy, from simple to + complex, singular $\rightarrow+$ general, general $\rightarrow+$ encyclopedia, concretes $\rightarrow+$ abstracts, examples $\rightarrow+$ Scholar states: "Indeed, teaching not to miss out on learning materials is not a hurry, a learning material plays a major role in ensuring consistency and consistency in teaching and learning.

Today, the importance of "prenapadia" plays an important role in family education. Therefore, it is vital that the Kuranic verses be broadcast from the time the child is in the womb, the child's faith 
in goodness, the child's creative work on the basis of Islamic values. For this reason, it is desirable to create all the necessary conditions for the Islamic values at the family polygon during the period of maternity leave. When speaking about Islamic values and principles of secular state, first of all, it should be born in mind that both have been built on the basis of the humanitarian values and values of human beings, including human freedoms, liberty, social justice, kindness, integrity, honesty, true words, avoiding sinful acts, good neighborliness, tolerance, humanity, peace and harmony in the family, non-discrimination, peace, brotherhood, mutual aid there are hundreds of humanitarian values such as support and hard work, and they are also valuable to the secular and the Islamic religion.

Consequently, in the issue of values, there is a great deal of universal values and values between the secular state and the Islamic religion, and this principle serves as the basis for the formation of Islamic values in the Karakalpak family. Among them, the range of values that provide freedom of man and freedom is one of the main principles of a secular democratic state. Consequently, the commonality and integrity of goals and principles is the key to the educational strategy. Muhammad Sodiq Orifi, a Muslim researcher, says this is the place where humanity can only be formed in a liberal environment. Liberty is evident in dozens of humanitarian systems, such as choosing a place of residence, traveling to different regions, freedom of religion, freedom of thought, and expression of freedom. Therefore, the practice of humiliating and restricting the religion of Islam and humanity cannot be mutually compatible and incompatible.

Therefore, pedagogically, the main pedagogical principle of forming the Islamic values in Karakalpak families is humanism, and the formation of education is based on both Islam and secular education. The national training program sets out the general principles for organizing education. It is said that "humanization of education serves to open the abilities of the person and to meet the diverse needs of his education, to ensure the priority of national and universal values, and the harmonization of human, social and environmental relations. These are the predominance of education, democratization, the education based on humanitarian values, humanism, socialization, national orientation, interdependence of education and upbringing, the creation of necessary conditions for identifying and educating talented youth. In this context, religion is a spiritual foundation, a guide star, a set of ideas that lead people to goodness, as a power that unites Muslims and encourages them to creativity, progress, and make the world beautiful.

The principle of unity of education and upbringing in the education system of Uzbekistan has been adopted. This principle is directed at the formation of a comprehensive human being. Because education and upbringing are the constitutional right of a person. According to the National Program for Training Personnel, "Human rights are the highest values of society. Human rights are an important constitutional institution. Human rights are a broader concept that embodies the aspirations and aspirations of all humanity."

The education system in Uzbekistan is directed to the individual, to stimulate it, to reveal its inner spiritual and intellectual resources. The religion of Islam is also directed to the individual. That is, the religion of Islam fully and precisely develops the daily religious and vital emotional and emotional functions of the Muslim, and, on this basis, responds to the question of who the Muslim is. Therefore, in the secular and the Islamic religion, pedagogy is directed to the individual. It is important for the religion of Islam to be the most comprehensive perfection of human beings, and it is essential that the religion of Islam is based on will, human qualities, intellectual development, creativity, social activity, justice in the society to properly manage their own life in the upbringing of a child.

To accomplish these tasks, it is said that the person should be educated. "Personality is the main subject and object of the system of training, consumers of educational services and their implementation," states the National Program for Training Personnel. One of the main requirements for forming Islamic values within a secular state is science. Islam is based on religious knowledge. The concept of science covers both secular sciences and religious sciences in Islam.

It is recognized that they exist in the universal integrity and unity. Islam calls Muslims to seek knowledge. Scholars are considered to be respected and respected in Islam, and that they must be respected. Scientists are included in the upper class. In Islamic interpretation, the roots of knowledge and belief are one, and both are based on the knowledge of the Creator's attributes. However, the way science and religion search for knowledge are different. In the Koran, it is said that "Allah is proud of those who seek knowledge". Knowledge is defined as obligatory upon every Muslim, that is, a duty that must be fulfilled. Muslims have been called upon to seek knowledge in history, that is, they must know their history well and deeply. The National Curriculum Program emphasizes that the knowledge given in the education system should be scientific and should rely on the latest achievements and 
discoveries in science, technology and technology. The science requires the development of personality based on the knowledge that has been proven and proven at the level of man's advanced science and technology achievements. Scientific knowledge covers all aspects of education, its content, forms, and methods.

Conclusions. The principle of historically plays an important role in the formation of Islamic values. In our region, especially in Movarounnahr, Islam and the Islamic spirituality, in particular the historical sequence of the spread of Islamic values, the development of the Islamic history and culture of great ancestors, the theory of prophesy, juristic studies, the essence of faith, the practice of the judiciary, the development of natural and humanistic sciences, literature, , along with the development of architecture, social sciences, especially Islamic philosophy, education and upbringing views have been recognized as achievements of world civilization.

\section{REFERENCES}

1. Кадрлар тайёрлаш миллий дастури // Баркамол авлод - Ўзбекистон тараққиётининг пойдевори. - Т.: Шарк, 1997. - 31-61 б.

2. Ян Амос Коменский. Буюк дидактика. -Тошкент: «Ўқитувчи», 1975. - Б. 159.

3. Бэртин Андре. Воспитание в утробе матери. -Москва, 1992.

4. Жданов Н.В. Исламская концепция миропорядка. - М., 1991216 с.

5. Мусурмонова О. Оила маънавияти - миллий ғурур. -Т.: Ўқитувчи, 1999. - 200 б. 